\title{
IMPLIKASI PEMBERLAKUAN UNDANG-UNDANG NO. 9 TAHUN 2015 TENTANG PERUBAHAN KEDUA UNDANG-UNDANG NO. 23 TAHUN 2014 TENTANG PEMERINTAH DAERAH ATAS PERIZINAN PERTAMBANGAN TERHADAP LEGISLASI DI DAERAH
}

\author{
Nurul Laili Fadhilah \\ Prodi Ilmu Hukum, Universitas Negeri Jember \\ Jl. Kalimantan No. 37, Jember \\ email:nulifadh@gmail.com
}

\begin{abstract}
Mines that have high economic value make various circles of society are encouraged to explore and exploit the natural resources that contains the value of the mine, including in the government both central and local governments at the provincial, regency / municipality assumed to get the local revenue of funding sources of mining in the area. Post implementation of Law No. 9 Year 2015 on the second amendment of Law No. 23 Year 2014 on Regional Government where it is implicated in the change of authority in the regions in terms of mining licensing authority in the area. Where the regime of local government legislation old one is still under the authority of the district / city, but after the enactment of new local government authority for granting mining licenses are no longer under the authority of district / city yet become the authority of the provincial government. The above conditions provide regulatory impact in the region to immediately follow up the enforcement of laws that the new government as a new regulation
\end{abstract}

Keyword: mining licensing, legislation

\begin{abstract}
Abstrak: Pertambangan yang memiliki nilai ekonomi tinggi membuat berbagai kalangan masyarakat terdorong untuk mengeksplorasi serta mengeksploitasi sumber daya alam yang mengandung nilai tambang, termasuk di kalangan pemerintah baik pemerintah pusat maupun pemerintah daerah di tingkat Provinsi, Kabupaten/Kota yang berasumsi untuk mendapatkan pendapatan asli daerah dari sumber pendanaan dari hasil pertambangan di daerah. Pasca pemberlakuan Undang-undang No. 9 Tahun 2015 Tentang Perubahan Kedua Undang-undang No. 23 Tahun 2014 Tentang Pemerintah Daerah dimana hal ini berimplikasi pada adanya perubahan kewenangan yang ada di daerah dalam hal kewenangan perizinan pertambangan di daerah. Dimana pada rezim undang-undang pemda yang lama masih menjadi kewenangan kabupaten/kota namun pasca pemberlakuan undang-undang pemda baru kewenangan atas pemberian izin pertambangan bukan lagi menjadi kewenangan kabupaten/ kota namun menjadi kewenangan pemerintah daerah provinsi. Kondisi di atas memberikan dampak regulasi di daerah untuk segera dapat menindaklanjuti pemberlakukan undang-undang pemda yang baru sebagai new regulation.
\end{abstract}

Kata Kunci: perizinan pertambangan, legislasi

Konstitusi telah mengamanahkan bahwa seluruh pengelolaan sumber daya alam yang ada di Indonesia telah diserahkan kepada negara, sehingga implikasi dari kondisi ini, pemerintah memiliki kewajiban untuk mengelola sumber daya alam yang ada baik itu pemerintah yang ada di pusat maupun pemerintah yang ada di daerah. Mengenai rumusan tersebut, terdapat penjelasan resmi mengenai makna "dikuasai oleh negara", namun satu hal yang telah disepakati bahwa dikuasai oleh negara tidak sama dengan dimiliki negara. Kesepakatan ini bertalian dengan atau suatu bentuk reaksi dari sistem atau konsep "domein" yang dipergunakan pada masa kolonial Hindia Belanda.

Konsep atau lebih dikenal dengan "asas domein" , mengandung pengertian kepemilikan (ownership). Negara adalah pemilik atas tanah, 
karena itu memiliki segala wewenang melakukan tindakan yang bersifat kepemilikan (eigensdaad) (Manan, 2004: 230.) Sedangkan Pasal 2 Ayat (2) dalam Undang-undang No.5 Tahun 1960 tentang Pokok-pokok Agraria merumuskan makna "hak menguasai negara" sebagai wewenang untuk: a) mengatur dan menyelenggarakan perubahan, penggunaan, persediaan dan pemeliharaan bumi, air dan ruang angkasa tersebut; b) menentukan dan mengatur hubungan-hubungan hukum antara orang-orang dengan bumi, air dan ruang agkasa; c) menentukan dan mengatur hubunganhubungan hukum mengenai bumi, air dan ruang angkasa.

Berdasarkan Pasal 143 Undang-undang No. 9 Tahun 2009 tentang Pertambangan dan Mineral Batubara, Bupati/walikota melakukan pembinaan dan pengawasan terhadap usaha pertambangan rakyat sesuai dengan peraturan perundangundangan yang yang diatur dengan Peraturan Daerah. Disinilah posisi daerah untuk dapat melakukan kewenangan yang ada berdasarkan pada peraturan perundang-undangan yang berlaku. Pada konteks otonomi daerah tidak serta merta kemudian menjadi kewenangan pemerintah daerah, di bidang pertambangan salah satunya, tugas-tugas pengelolaan di bidang pertambangan bukanlah tugas yang bersifat kedaerahan, sehingga tidak dapat diserahkan kepada pemerintah daerah. Perlu digarisbawahi bahwa urusan yang diserahkan kepada daerah adalah urusan yang bersifat lokal, artinya mempunyai nilai yang bersifat kedaerahan, sesuai dengan kondisi daerah dan tidak menyangkut kepentingan nasional.

Mengacu pada ketentuan pertama, yakni pada rezim Pasal 10 Undang-undang No. 32 Tahun 2004 tentang Pemerintah Daerah sebelum Undang-undang No. 23 Tahun 2014 tentang Pemerintah Daerah diberlakukan bahwa "Kewenangan daerah meliputi seluruh kewenangan bidang pemerintahan kecuali dalam bidang politik luar negeri, pertahanan, keamanan, yustisi, moneter dan fiskal nasional serta agama. Dipertegas dalam ayat (1) Pemerintahan daerah menyelenggarakan urusan pemerintahan yang menjadi kewenangannya, kecuali urusan pemerintahan yang oleh Undang Undang ini ditentukan menjadi urusan Pemerintah. Serta diperinci dalam ayat (3) bahwa urusan pemerintahan yang menjadi urusan Pemerintah sebagaimana dimaksud pada ayat (1) meliputi : politik luar negeri, pertahanan; keamanan; yustisi; moneter dan fiskal nasional; dan Agama.

Kemudian berdasarkan pengaturan di atas, maka secara a contario urusan pemerintahan di bidang pertambangan termasuk pada penggolongan urusan rumah tangga daerah. Akan tetapi pengaturan dalam Pasal 13, kewenangan pada bidang pertambangan bukan merupakan urusan wajib tetapi urusan pilihan, dimana secara nyata ada dan dapat meningkatkan kesejahteraan masyarakat sesuai dengan kondisi dan kekhasan dan potensi unggulan daerah yang bersangkutan. Sehingga perlu diperjelas, hal tentang kewenangan dibidang pertambangan baik itu yang bersifat mengatur (regelen), mengurus (besturen) dan mengawasi (toetzicthhouden). Dalam hal penerapan hak penguasaan negara atas tambang yang dimiliki, tidak berarti negara sebagai pemilik tapi hal ini merujuk pada hak eksklusif yang melekat pada negara. Sehingga dari konteks ini, negara memiliki kewenangan penuh untuk menentukan kebijakan dalam bentuk tiga kewenangan atas pengusahaan pertambangan.

Pada poin inilah terdapat keterkaitan dengan bentuk kebijakan dan penguasaan di bidang pertambangan, namun harus tetap melihat karakter dan lokalitas dari daerah yang bersangkutan dalam melaksanakan kewenangan urusan pertambangan. Bangsa Indonesia sebagai pemilik kekayaan atas seluruh sumber daya alam yang terkandung di dalamnya memberikan pengamanahan kepada pemerintah untuk dapat menyelenggarakan kewenangan yang setinggi-tingginya untuk kemudian dapat dipergunakan sebaik-baiknya demi kemakmuran rakyat Indonesia. Karena dengan melibatkan peran serta dari masyarakat tentunya akan mempermudah dilakukannya suatu pengawasan dalam pengelolaannya.

Berdasarkan pada rezim pengaturan di dalam Undang-undang No. 9 Tahun 2015 tentang Perubahan Kedua Undang-undang No. 23 Tahun 2014 tentang Pemerintah Daerah terutama kaitannya dengan pengelolaan pertambangan di daerah. Hal ini terlihat pada kebijakan baru dalam Pasal 10 Undang-undang No. 9 Tahun 2015 tentang Perubahan Kedua Undang-undang No. 23 Tahun 2014 tentang Pemerintah Daerah bahwa kewenangan penyelenggaraan pemerintah dalam hal pertambangan menjadi kewenangan dari pemerintah daerah dan dipertegas dalam lampiran Undang-undang Pemda bahwa pada tingkat pemerintah daerah, urusan pemerintahan di bidang 
energi dan sumber daya mineral yang berada di wilayah pemerintah daerah diamanahkan kepada pemerintah provinsi dimana kewenangan tersebut diantara lain untuk melakukan (1) penetapan wilayah izin usaha pertambangan mineral bukan logam dan batuan dalam 1 (satu) Daerah provinsi dan wilayah laut sampai dengan $12 \mathrm{mil}$, (2) Penerbitan izin usaha pertambangan mineral logam dan batubara dalam rangka penanaman modal dalam negeri pada wilayah izin usaha pertambangan Daerah yang berada dalam 1 (satu) Daerah provinsi termasuk wilayah laut sampai dengan 12 mil laut, (3) penerbitan izin usaha pertambangan mineral bukan logam dan batuan dalam rangka penanaman modal dalam negeri pada wilayah izin usaha pertambangan yang berada dalam 1 (satu) Daerah provinsi termasuk wilayah laut sampai dengan 12 mil laut, (4) Penerbitan izin pertambangan rakyat untuk komoditas mineral logam, batubara, mineral bukan logam dan batuan dalam wilayah pertambangan rakyat, (5) Penerbitan izin usaha pertambangan operasi produksi khusus untuk pengolahan dan pemurnian dalam rangka penanaman modal dalam negeri yang komoditas tambangnya berasal dari 1 (satu) Daerah provinsi yang sama, (6) Penerbitan izin usaha jasa pertambangan dan surat keterangan terdaftar dalam rangka penanaman modal dalam negeri yang kegiatan usahanya dalam 1 (satu) Daerah provinsi, dan (7) Penetapan harga patokan mineral bukan logam dan batuan. Sehingga dari adanya kondisi tersebut memberikan dampak bahwa pemerintah daerah setingkat Kabupatan/Kota terdapat perubahan kewenangan dalam hal pengelolaan serta regulasi kaitannya dengan masalah perizinan pertambangan yang berada di daerahnya. Adanya perbedaan rezim yang mengatur maka perlu dilakukan upaya analisa terkait dengan hal di atas tentang kajian kewenangan pemerintah daerah kaitannya dengan perbahan rezim yang dibawa oleh undang-undang pemda baru terhadap proses legislasi di daerah khususnya dalam perizinan pertambangan di daerah.

\section{PERIZINAN TAMBANG DI TINGKAT DAERAH}

Berdasarkan pada Pasal 18 (2) UUD 1945 , pemerintah daerah diberikan kewenangan untuk menjalankan otonomi seluas-luasnya.
Kewenangan tersebut tentunya memberikan peluang adanya upaya untuk lebih mandiri serta meningkatkan fungsi penyelenggaraan pemerintahan daerah yang lebih efektif dan efisien. Pada level pemerintah daerah upaya efisiensi dan efektifitas yang dimaksud banyak menyentuh pada pelayanan publik, pengelolaan keuangan daerah sampai pada peningkatan sumber daya alam yang menjadi komoditi bagi daerah dalam meningkatkan pendapatan asli daerah (PAD). Salah satu upaya tersebut dengan membuat regulasi serta kebijakan yang diformulasikan dalam Peraturan Daerah yang berimbas pada regulasi yang bertujuan untuk meningkatkan pendapatan asli daerah.

Implikasi dari fenomena tersebut mendorong pemerintah daerah untuk melakukan upaya peningkatan pendapatan dari berbagai lini termasuk pengelolaan sumber daya alam berupa tambang mineral yang menjadi andalan daerah untuk dapat dijadikan sebagai komoditi dalam peningkatan pendapatan asli daerah. Namun tentunya eksploitasi atas pengelolaan pertambangan mineral ini harus berprinsipkan pada usaha pertambangan yang berwawasan lingkungan serta pembangunan berkelanjutan. Sebagaimana banyak di daerah yang memiliki potensi sumber daya alam yang sangat potensial, pengelolaan pertambangan mineral masih belum secara maksimal dilakukan karena banyaknya unsur kepentingan yang harus didahulukan. Ditambah lagi adanya tarik ulur kepentingan dari satu peraturan dengan peraturan yang lainnya. Karena jelas jika membahas menyenai pertambangan maka tidak hanya fokus pada pengaturan tentang pertambangan saja, harus ada kajian-kajian mendalam yang saling berhubungan diantaranya pengaturan tentang kewenangan urusan pemerintahan, lingkungan hidup, perizinan dan lainlain.Berdasarkan pada pendapat dari Soepomo, dapat dikonstruksikan dalam gambar mengenai penyelenggaraan atas kekayaan alam tersebut, sesuai dengan kewenangan pemerintah, melalui lembaga-lembaga yang dibentuk dapat melakukan kerjasama pengusahaan pertambangan dengan pihak lain sebagai pelaksana "pengusahaan" pertambangan seperti gambar 1 (Soepomo, 2009).

Berdasarkan pada penggambaran yang disampaikan oleh Soepmo, bahwa dalam pelaksaan pengelolaan pertambangan di era otonomi pada rezim Undang-undang No. 32 Tahun 2004 tentan Pemerintah Daerah sebelumnya 
Gambar 1. Lembaga dalam Pengusahaan Pertambangan

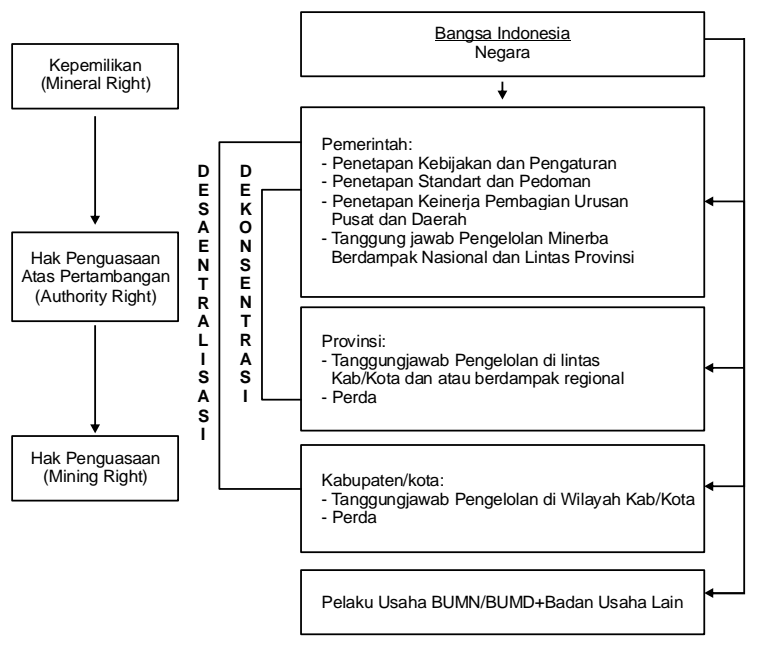

terdapat persepsi tentang konsep "penguasaan" dan "pengusahaan" sering bercampur aduk dalam penafsiran yang salah. Sedangkan untuk pengaturan yang kedua adalah berdasarkan pengaturan dalam Undang-undang No. 33 Tahun 2004 tentang Perimbangan Keuangan antara Pemerintah dan Pemerintah Daerah, dimana pembagian besaran penerimaan dari sektor pertambangan antara Pemerintah dan Pemerintah Daerah bergantung pada masing-masing sektor dalam bidang pertambangan, misalkan di sektor pertambangan pada Pasal 14 huruf c dan Pasal 17 (1), (2), (3) Undang-undang No. 33 Tahun 2004 Perimbangan Keuangan antara Pemerintah dan Pemerintah Daerah bahwa royalti untuk pemeritah sebesar $20 \%$ dan daerah $80 \%$ yang diperinci lagi menjadi provinsi (16\%, daerah pengahsil $32 \%$ dan $32 \%$ sisinya adalan untuk Kabupaten/Kota lainnya dalam provinsi yang bersangkutan). Hal ini menunjukkan bahwa meskipun daerah memiliki kekayaan alam yang melimpah daerah yang menghasilkan kegiatan pertambangan tersebut tidak bisa dikatakan meningkat pendapatannya. Hal tersebut makin diperkuat dengan adanya regulasi atas pembagian hasil yang diperoleh dari pengelolaan sumber daya alam tersebut, selain itu dengan adanya regulasi tersebut menempatkan posisi pemerintah memperoleh pembagian hasil yang lebih besar, sehingga dari kondisi tersebut memberikan peluang pemerintah untuk campur tangan di sektor pertambangan dengan begitu dapat terwujud kepentingan nasional, sehingga nantinya dapat memperoleh hasil yang maksimal dari sektor pengelolaan di sektor pertambangan dengan mengacu pada seluruh kesejahteraan rakyat Indonesia.

Sedangkan Pasal 8 Undang-undang No. 4 Tahun 2009 tentang Pertambangan Mineral dan Batubara, dimana disebutkan bahwa kewenangan pemerintah Kabupaten/kota dalam pengelolaan pertambangan diantaranya adalah sebagai berikut: a) pembuatan peraturan perundang-undangan daerah; b) pemberian IUP dan IPR, pembinaan, penyelesaian konflik masyarakat, dan pengawasan usaha pertambangan di wilayah kabupaten/kota dan/atau wilayah laut sampai dengan 4 (empat) mil; c) pemberian IUP dan IPR, pembinaan, penyelesaian konflik masyarakat dan pengawasan usaha pertambangan operasi produksi yang kegiatannya berada di wilayah kabupaten/kota dan/atau wilayah laut sampai dengan 4 (empat) mil; d) penginventarisasian, penyelidikan dan penelitian, serta eksplorasi dalam rangka memperoleh data dan informasi mineral dan batubara; e) pengelolaan informasi geologi, informasi potensi mineral dan batubara, serta informasi pertambangan pada wilayah kabupaten/ kota; f) penyusunan neraca sumber daya mineral dan batubara pada wilayah kabupaten/kota; g) pengembangan dan pemberdayaan masyarakat setempat dalam usaha pertambangan dengan memperhatikan kelestarian lingkungan; $h$ ) pengembangan dan peningkatan nilai tambah dan manfaat kegiatan usaha pertambangan secara optimal; i) penyampaian informasi hasil inventarisasi, penyelidikan umum, dan penelitian, serta eksplorasi dan eksploitasi kepada Menteri dan gubernur; j) penyampaian informasi hasil produksi, penjualan dalam negeri, serta ekspor kepada Menteri dan gubernur; k) pembinaan dan pengawasan terhadap reklamasi lahan pascatambang; dan 1) peningkatan kemampuan aparatur pemerintah kabupaten/kota dalam penyelenggaraan pengelolaan usaha pertambangan.

Pasca Lahirnya Undang-undan No. 23 Tahun 2014 tentang Pemerintah Daerah, maka terdapat perubahan pola kebijakan dalam hal pemetaan penyelengaraan urusan pemerintahan yang sifatnya afirmatif dan akan menjadi priotitas daerah dalam melaksanakan otonomi yang seluasluasnya. Sehingga dari adanya pemetaan tersebut akan tercipta sinergitas lembaga yang urusan pemerintahannya di desentralisasikan ke daerah. Karena dengan adanya sinergitas dari masing- 
masing lembaga akan menciptakan sinergitas urusan pemerintahan secara nasional dari tingkat lembaga, provinsi hingga kabupaten/kota. Manfaatnya adalah akan tercipta penyaluran dana bantuan yang terarah dari kementrian. Hal ini akan sulit terwujud jika tanpa adanya dukungan dari stakeholder yang memadai dalam jumlah dan standar kompetensi yang diperlukan untuk melaksanakan urusan pemerintahan yang menjadi kewenangan pemerintah daerah.

Oleh karena itu untuk memperkuat otonomi daerah salah satunya adalah dengan mekanisme pembinaan, pengawasan, pemberdayaan serta sanksi yang jelas dan tegas. Adanya pembinaan dan pengawasan yang jelas tersebut maka akan terwujud adanya pemberdayaan daerah dalam penyelenggaraan pemerintahan daerah. Sama halnya dengan salah satu rezim baru yang disampaikan oleh Undang-undang No. 9 Tahun 2015 tentang Perubahan Kedua Undang-undang No. 23 Tahun 2014 tentang Pemerintah Daerah terutama kaitannya dengan pengelolaan pertambangan di daerah. Hal ini terlihat pada kebijakan baru dalam Pasal 10 Undang-undang No. 9 Tahun 2015 tentang Perubahan Kedua Undang-undang No. 23 Tahun 2014 tentang Pemerintah Daerah bahwa kewenangan penyelenggaraan pemerintah dalam hal pertambangan menjadi kewenangan dari pemerintah daerah dan dipertegas dalam lampiran Undang-undang Pemda bahwa pada tingkat pemerintah daerah, urusan pemerintahan di bidang energi dan sumber daya mineral yang berada di wilayah pemerintah daerah diamanahkan kepada pemerintah provinsi dimana kewenangan tersebut diantara lain untuk melakukan (1) penetapan wilayah izin usaha pertambangan mineral bukan logam dan batuan dalam 1 (satu) Daerah provinsi dan wilayah laut sampai dengan $12 \mathrm{mil}$, (2) Penerbitan izin usaha pertambangan mineral logam dan batubara dalam rangka penanaman modal dalam negeri pada wilayah izin usaha pertambangan Daerah yang berada dalam 1 (satu) Daerah provinsi termasuk wilayah laut sampai dengan 12 mil laut, (3) penerbitan izin usaha pertambangan mineral bukan logam dan batuan dalam rangka penanaman modal dalam negeri pada wilayah izin usaha pertambangan yang berada dalam 1 (satu) Daerah provinsi termasuk wilayah laut sampai dengan $12 \mathrm{mil}$ laut, (4) Penerbitan izin pertambangan rakyat untuk komoditas mineral logam, batubara, min- eral bukan logam dan batuan dalam wilayah pertambangan rakyat, (5) Penerbitan izin usaha pertambangan operasi produksi khusus untuk pengolahan dan pemurnian dalam rangka penanaman modal dalam negeri yang komoditas tambangnya berasal dari 1 (satu) Daerah provinsi yang sama, (6) Penerbitan izin usaha jasa pertambangan dan surat keterangan terdaftar dalam rangka penanaman modal dalam negeri yang kegiatan usahanya dalam 1 (satu) Daerah provinsi, dan (7) Penetapan harga patokan mineral bukan logam dan batuan.

Selain itu juga terdapat pengaturan yaitu Pasal 4 ayat 2, 3, dan 4 dalam Peraturan Menteri Dalam Negeri No. 1 Tahun 2014 tentang tentang Pembentukan Produk Hukum Daerah dimana terdapat penyempurnaan dalam proses pembentukan Produk Hukum Daerah. Salah satunya diantaranya adalah penambahan akan kebijakan tentang Perda Provinsi yang memiliki hierarki yang lebih tinggi dibandingkan dengan perda Kabupaten/Kota, bahwa perda Provinsi memuat materi muatan untuk mengatur kewenangan provinsi dan/atau dapat mengatur kewenangan Kabupaten/Kota dan Perda Provinsi dapat mengatur kewenangan Kabupaten/Kota apabila terdapat pengaturan yang materi muatannya terkait Kabupaten/Kota.

\section{PASCA PEMBERLAKUAN UNDANG- UNDANG NO. 9 TAHUN 2015 TENTANG PERUBAHAN KEDUA UNDANG- UNDANG NO. 23 TAHUN 2014 TENTANG PEMERINTAH DAERAH}

Seperti dinyatakan sebelumnya bahwa berdasarkan pada Pasal 8 Undang-undang No. 4 Tahun 2009 tentang Pertambangan dan Mineral Batubara bahwa pemerintah kabupaten/kota diberi kewenangan untuk mengatur hal terkait dengan regulasi pengelolaan pertambangan. Berbeda halnya dengan regulasi terbaru dalam Undangundang N0. 23 Tahun 2014 tentang Pemerintah Daerah, bahwa di level pemerintah daerah kabupaten/kota, pemerintah tidak lagi diberi kewenangan atas pengelolaan pertambangan karena semua kewenangan tersebut dialihkan kepada Pemerintah daerah selaku wakil di daerah tingkat kabupaten/kota untuk melakukan kewenangan atas urusan pemerintah daerah di bidang pertambangan, sehingga di sini Pemerintah Kabupaten/Kota hanya mendapatkan bagi hasil 
Gambar 2. Pembagian urusan Pemerintahan Rezim Undang-undang No. 9 Tahun 2015 tentang Perubahan Kedua Undang-undang No. 23 Tahun 2014 tentang Pemerintah Daerah

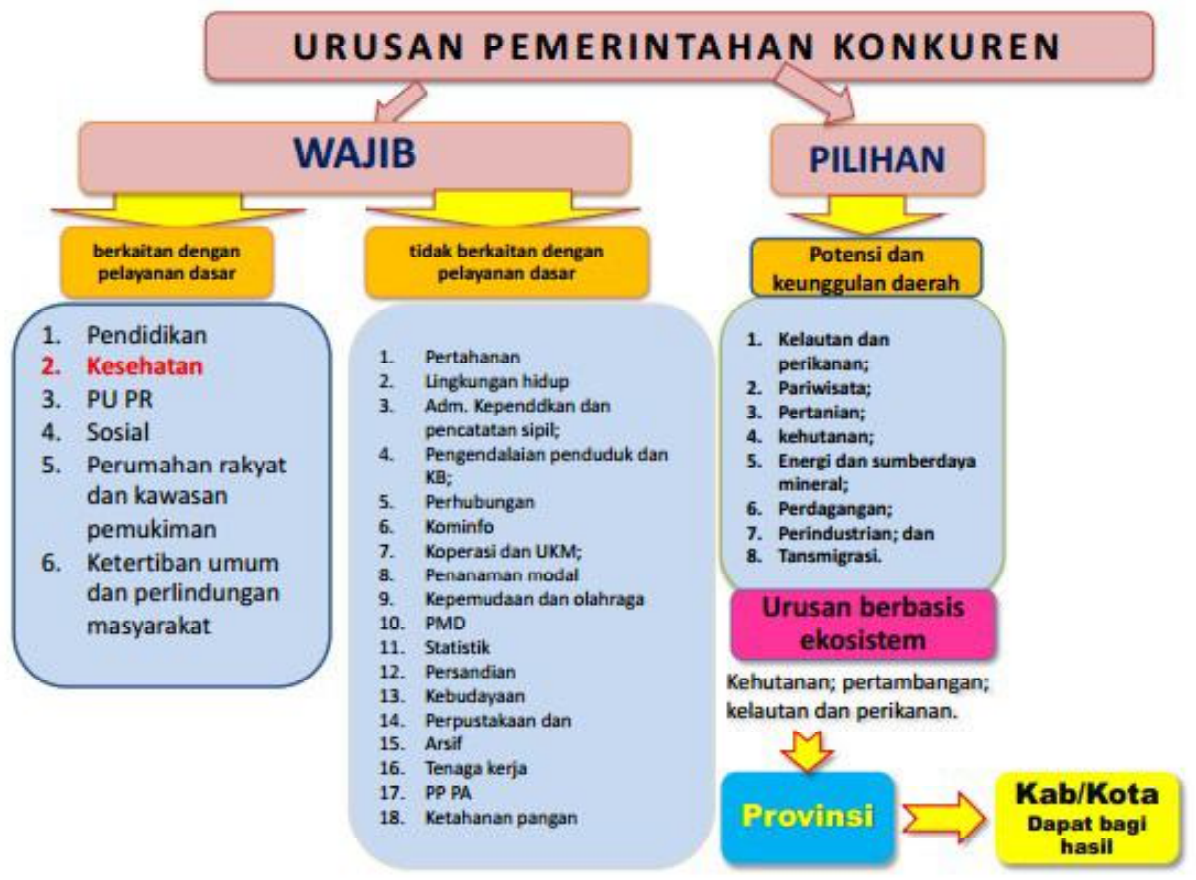

Sumber : Kementrian Dalam Negeri dalam Implementasi Undang-undang No. 23 Tahun 2014 Pembagian Peran Antara Pemerintah Pusat, Provinsi dan Kabupaten/Kota.

Gambar 3 Urusan Pemerintahan Derah di bidang Pengelolaan Tambang

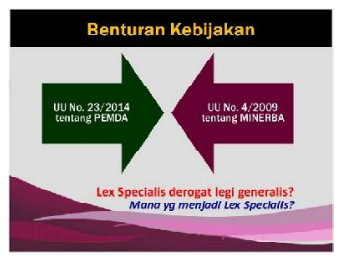

\section{Kewenangan Prov. Bidang ESDM}

\begin{tabular}{l} 
UU Pemda \\
\hline 1. Penetapan wilayah izin UP mineral bukan logam dan batuan dalam 1 \\
provinsi dan wilayah laut s/d 12 mil. \\
2. Penerbitan izin UP mineral logam dan batubara dalam rangka PMDN \\
pada wilayah izin UP yg berada dalam 1 provinsi termasuk wilayah laut \\
s/d 12 mil laut. \\
3. Penerbitan izin UP mineral bukan logam dan batuan dalam rangka \\
PMDN pada wilayah izin UP yg berada dalam 1 provinsi termasuk \\
wilayah laut s/d 12 mil laut. \\
4. Penerbitan izin pertambangan rakyat untuk komoditas mineral logam, \\
batubara, mineral bukan logam dan batuan dalam wilayah \\
pertambangan rakyat. \\
5. Penerbitan izin UP operasi produksi khusus untuk pengolahan dan \\
pemurnian dalam rangka PMDN yg komoditas tambangnya berasal dari \\
1 provinsi yg sama. \\
6. Penerbitan izin usaha jasa pertambangan dan surat keterangan terdaftar \\
dalam rangka PMDN yg kegiatan usahanya dalam 1 provinsi. \\
7. Penetapan harga patokan mineral bukan logam dan batuan.
\end{tabular}

Kewenangan Prov. Bidang ESDM

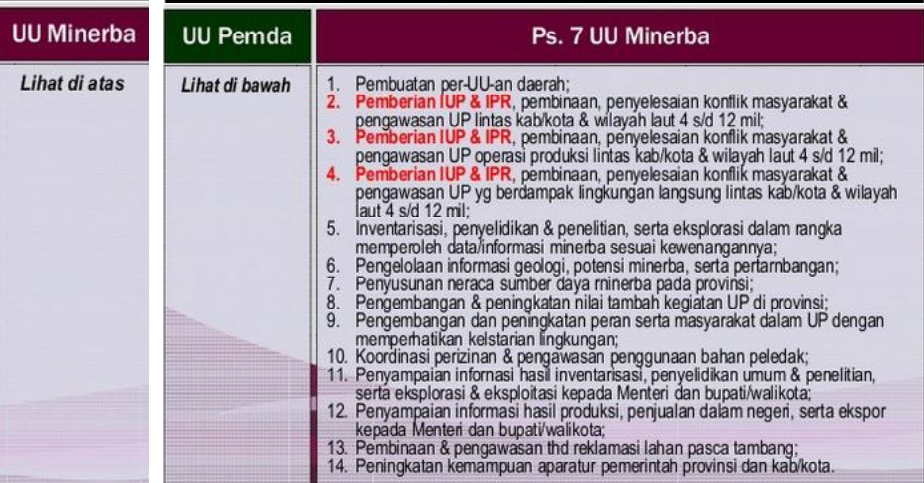

Sumber: Kementrian Dalam Negeri, diolah Tahun 2014 
dari usaha pengelolaan pertambangan di daerah. Sebagaimana dalam gambar 2.

Hal ini makin diperjelas pada gambar 3 bahwa Undang-undang pemda baru sebagai pengaturan dasar dalam penyelenggaraan pemerintah baik pusat maupun daerah mensederhanakan urusan pemerintahan di daerah pada bidang pertambangan yang awalnya mencapai 18 poin disederhanakan menjadi 7 poin saja. Hal ini mendukung adanya efisiensi serta efektifitas dalam hal penyelenggaraan perizinan pertambangan di daerah. Implikasinya yuridisnya pemerintah daerah Kabupaten/Kota sama sekali tidak memiliki kewenangan untuk melakukan pengelolaan, termasuk dalam hal regulasi di bidang pertambangan.

Berdasarkan gambaran dalam sketsa yang disampaikan oleh auditor, maka dari adanya gambaran tersebut diberikan penjelasan bahwa terdapat pola perubahan kebijakan dalam urusan pemerintahan di bidang energi dan sumber daya mineral dengan wilayah cakupan pada bidang pertambangan mineral dan batubara hanya terdapat 2 urusan yang diatur yakni untuk pemerintah pusat dan pemerintah daerah provinsi. Adapun untuk urusan pemerintah yang menjadi kewenangan dari pemerintah pusat diantaranya adalah sebagai berikut: a) Penetapan wilayah pertambangan sebagai bagian dari rencana tata ruang wilayah nasional, yang terdiri atas wilayah usaha pertambangan, wilayah pertambangan rakyat dan wilayah pencadangan negara serta wilayah usaha pertambangan khusus; b) penetapan wilayah izin usaha pertambangan mineral logam dan batubara serta wilayah izin usaha pertambangan khusus; c) Penetapan wilayah izin usaha pertambangan mineral bukan logam dan batuan lintas Daerah provinsi dan wilayah laut lebih dari 12 mil; d) Penerbitan izin usaha pertambangan mineral logam, batubara, mineral bukan logam dan batuan pada: 1) wilayah izin usaha Pertambangan yang berada pada wilayah lintas Daerah provinsi; 2) wilayah izin usaha pertambangan yang berbatasan langsung dengan negara lain; dan 3) wilayah laut lebih dari $12 \mathrm{mil}$; e) Penerbitan izin usaha pertambangan dalam rangka penanaman modal asing; f) Pemberian izin usaha pertambangan khusus mineral dan batubara; g) Pemberian registrasi izin usaha pertambangan dan penetapan jumlah produksi setiap Daerah provinsi untuk komiditas mineral logam dan batubara; h)
Penerbitan izin usaha pertambangan operasi produksi khusus untuk pengolahan dan pemurnian yang komoditas tambangnya yang berasal dari Daerahprovinsi lain di luar lokasi fasilitas pengolahan dan pemurnian, atau impor serta dalam rangka penanaman modal asing; i) Penerbitan izin usaha jasa pertambangan dan surat keterangan terdaftar dalam rangka penanaman modal dalam negeri dan penanaman modal asing yang kegiatan usahanya di seluruh wilayah Indonesia; j) Penetapan harga patokan mineral logam dan batubara; k) Pengelolaan inspektur tambang dan pejabat pengawas pertambangan.

Sedangkan untuk urusan pemerintah yang menjadi kewenangan dari pemerintah daerah provinsi dalam bidang mineral dan batubara adalah sebagai berikut: a) penetapan wilayah izin usaha pertambangan mineral bukan logam dan batuan dalam 1 (satu) Daerah provinsi dan wilayah laut sampai dengan 12 mil; b) Penerbitan izin usaha pertambangan mineral logam dan batubara dalam rangka penanaman modal dalam negeri pada wilayah izin usaha pertambangan Daerah yang berada dalam 1 (satu) Daerah provinsi termasuk wilayah laut sampai dengan 12 mil laut,; c) penerbitan izin usaha pertambangan mineral bukan logam dan batuan dalam rangka penanaman modal dalam negeri pada wilayah izin usaha pertambangan yang berada dalam 1 (satu) Daerah provinsi termasuk wilayah laut sampai dengan 12 mil laut; d) Penerbitan izin pertambangan rakyat untuk komoditas mineral logam, batubara, mineral bukan logam dan batuan dalam wilayah pertambangan rakyat; e) Penerbitan izin usaha pertambangan operasi produksi khusus untuk pengolahan dan pemurnian dalam rangka penanaman modal dalam negeri yang komoditas tambangnya berasal dari 1 (satu) Daerah provinsi yang sama; f) Penerbitan izin usaha jasa pertambangan dan surat keterangan terdaftar dalam rangka penanaman modal dalam negeri yang kegiatan usahanya dalam 1 (satu) Daerah provinsi; dan g) Penetapan harga patokan mineral bukan logam dan batuan.

Tidak adanya kewenangan untuk pemerintah daerah atas urusan pemerintahan di bidang pertambangan mineral dan batubara memberikan konsekuensi hukum bahwa pemerintah daerah kabupaten kota tidak lagi diberikan kewenangan berdasarkan pengaturan kebijakan dalam Undangundang No. 9 Tahun 2015 tentang Perubahan 
Kedua Undang-undang No. 23 Tahun 2014 tentang Pemerintah Daerah. Hal ini menunjukkan bahwa seluruh pengelolaan terkait dengan penerbitan izin-izin usaha pertambangan bukan lagi menjadi kewenangan dari pemerintah daerah kabupaten/kota. Sampai pada tahap ini auditor perlu menjelaskan detail bahwa pasca lahirnya Undang-undang Pemda baru akan melahirkan banyak pertentangan maupun dinamika dalam hal penerbitan izin di wilayah pemerintah Kabupaten/ Kota, karena realitanya di lapangan sebelum undang-undang baru ini terbit banyak pemerintah daerah yang telah melakukan penerbitan izin terutama untuk izin usaha pertambangan di wilayah kabupaten/kota. Termasuk dalam hal kebijakan regulasi yang banyak mengalami perombakan atau bahkan tidak lagi diatur karena dalam regulasi yang baru tidak disebutkan secara nyata bahwa pemerintah kabupaten/kota memiliki kewenangan untuk mengatur ataupun memberikan izin terkait dengan usaha pertambangan yang ada di wilayahnya. Meskipun urusan pemerintah di bidang pertambangan mineral batubara menjadi kewenangan dari pemerintah daerah namun dipertegas kembali dalam lampiran Undangundang Pemda yang baru bahwa kewenangan bagi pemerintah daerah hanya diberikan kepada Pemerintah daerah provinsi sebagai kendali di daerah dalam hal pengelolaan pertambangan.

Dalam konteks regulasinya tentu perlu diingat bahwa dalam setiap pembentukan peraturan perundang-undangan dikenal adanya 3 asas yang mendasari dibentuknya suatu peraturan perundangundangan, diantanya adalah 1) Azas Lex Superior derogate lex inferior, Peraturan yang lebih tinggi akan mengesampingkan peraturan yang lebih rendah apabila mengatur subtansi yang sama dan bertentangan. 2) Azas Lex Specialist derogate lex generalis, Peraturan yang lebih khusus akan mengesampingkan peraturan yang umum apabila mengatur subtansi yang sama dan bertentangan. 3) Azas Lex Posterior derogate lex priori, Peraturan yang baru akan mengesampingkan peraturan yang lama. Pada pembahasan ini tentunya auditor mengarah pada proses pembentukan peraturan perundang-undangan yang menganut asas Lex Posterior derogate lex priori, dimana peraturan yang baru akan mengesampingkan peraturan yang lama. Hal ini disebabkan karena kedudukan dari Undang-undang No. 9 Tahun 2015 tentang Perubahan Kedua Undang-undang No. 23 Tahun 2014 tentang
Pemerintah Daerah sifatnya lebih baru dan mengatur secara umum kaitannya dengan penyelenggaraan urusan pemerintahan baik di pusat dan di daerah. Implikasi yuridis yang dibangun adalah dari keseluruhan peraturan yang ada setelah undang-undang ini diberlakukan berimbas pada beberapa peraturan yang dicabut dan dinyatakan tidak berlaku. Adapun peraturan yang dinyatakan dicabu dan tidak berlaku lagi dalam uu pemda diantaranya adalah Undang-undang No. 5 Taun 1962 tentang Perusahaan Daerah, Undang-undang No. 32 Tahun 2004 tentang Pemeirntah Daerah, kemudian pasal-pasal tertentu dalam Undangundang No. 28 Tahun 2009 tentang Pajak Daerah dan Retribusi Daerah serta pasal tertentu dalam Undang-undang No. 17 Tahun 2014 tentang MD3.

Kaitannya dengan masalah pengelolaan pertambangan tentunya mengalami hal yang berbeda. Karena sebagaimana diketahui bahwa pada Undang-undang pertambangan dan mineral batubara sifatnya khusus. Tetapi perlu diingat bahwa unsur kebaruan dalam hal legal audit perlu ditekankan. Kebijakan dalam hal urusan pemerintah yang menjadi kewenangan baik itu pemerintah pusat dan pemerintah daerah yang sifatnya lebih umum dan baru tentunya memiliki posisi yang lebih tinggi dibandingkan dengan regulasi yang sifatnya lebih lama dan khusus, oleh karenanya dalam ini dilakukan upaya harmonisasi paraturan perundang-undangan yang ada. Sehingga dalam hal ini tidak terjadi apa yang dinamakan hukum tidak berjalan sebagaimana mestinya yang mengakibatkan ketertiban dan kepatuhan hukum tidak dapat terlaksana dengan baik. Maka dari itu untuk menghindari adanya kondisi tersebut maka sebagai konsekuensi logis dari adanya pengaturan yang baru tersebut yang sifat pengaturannya lebih baru dan bersifat umum tentunya mengesampingkan peraturan yang sifatnya lebih lama dan bersifat khusus, seperti halnya dalam pengaturan masalah pertambangan. Sehingga dari sini undang-undang Pemda yang digunakan sebagai acuan dalam prose maupun mekanisme yang paling baru dalam hal urusan pemerintahan yang menjadi kewenangan pemerintah daerah kaitannya di bidang pertambangan dan mineral batubara.

Alasannya bahwa dari adanya sifat peraturan perundang-undangan dari UU Pemda yang mengatur lebih umum inilah yang menjadikan kedudukan dari UU pemda baru lebih tinggi dibandingkan dengan UU tentang minerba. Dari 
adanya kedudukan yang lebih tinggi tersebut tentunya berimbas pada penyelenggaran perizinan di daerah sebelumnya yang mengacu pada uu minerba. Jika pada rezim UU pemda baru dinyatakan bahwa kabupaten/kota tidak memiliki kewenangan atas penerbitan izin maka untuk penerbitan izin yang sudah diterbitkan oleh kabupaten/kota yang mengacu pada UU minerba masih dinyatakan berlaku dan perlu dilakukan masa penyesuaian terhadap izin-izin usaha pertambangan yang sudah terbit pasca pemberlakukan uu pemda baru.

Terdapat ruang bagi pemerintah daerah yang sudah mengeluarkan izin-izin terkait dengan usaha pertambangan sebelum berlakunya undangundang yang baru tetap dinyatakan berlaku sampai dengan masa berlakunya izin tersebut dan bagi BUMD yang telah ada sebelum undang-undang yang baru ini berlaku wajib melakukan penyesuaian terhadap regulasi yang baru dan diberikan tenggang waktu selama 3 tahun untuk melakukan penyesuaian.

Dalam hal perizinan yang diberikan pada pemerintah daerah tidak sedikitpun menyebutkan Kabupaten/kota berwenang atas penebitan izin usaha pertambangan, hal ini berimplikasi bahwa daerah tidak lagi memiliki kewenangan dalam hal pengelolaan pertambangan termasuk dalam penyusunan kebijakan regulasinya. Karena semua izin usaha pertambangan yang ada di handel oleh pemerintah provinsi sebagai pengelola wilayah tambang yang berada dalam kesatuan wilayahnya dalam 1 provinsi. Sehingga dari sini tidak ada hak dari Bupati/Walikota untuk menerbitkan izin usaha pertambangan.

Kabupaten sebagai sub ordinasi pemerintah memiliki kewajiban tunduk, patuh dan loyal terhadap sistem besar ketatanegaraan di republik ini baik dalam perspektif regulasi, manajemen penyelenggaraan pemerintah, dan ketatalaksanaan lainnya. Dengan kata lain apa yang menjadi arah penyelenggaraan pemerintahan di kabupaten persis harus berada di titik sub ordinat pemerintah pusat secara trandsendental. Oleh karenanya kabupaten akan merasa kebingungan tatkala terdapat permasalahan menyangkut substansi penyelenggaraan Satuan Kerja Pemerintah Daerah (SKPD) yang notabene sebagai pengampu urusan, tetapi terbentur oleh regulasi yang belum jelas di tingkat pusat.

Kita mengetahui bersama bahwa UU 23 Tahun 2014 adalah merupakan pintu masuk penyelenggaraan pemerintahan daerah. Dalam struktur hukum di Indonesia tentu saja regulasi tersebut tidak serta merta dapat dilaksanakan di tingkat bawah seperti halnya kabupaten dan diperlukan produk hukum turunan yang lebih teknis menjelaskan konten yang lebih rinci seperti Peraturan Pemerintah (PP) sebagai amanah harus terbentuk maksimum 2 (dua) tahun setelah diterbitkannya UU. Turunan ini akan segera ditindaklanjuti dengan peraturan kementrian yang lain yang akan di tangkap oleh kabupaten seluruh Indonesia sebagai modal awal penyusunan Peraturan Daerah maupun Peraturan Kepala daerah yang diamanatkan dalam pasal 236 UU ini.

Melihat permasalahan yang ada upaya yang mendasar perlu dilakukan oleh pemerintah pusat adalah segera menindaklanjuti bagaimana membuat regulasi turunan dari UU 23, karena difahami bahwa kabupaten tidak akan mungkin potong kompas membuat produk hukum daerah jika belum ada produk hukum lanjutan (intermediate). Terlebih lagi berdasarkan UU 23 terdapat beberapa kewenangan strategik yang selama ini dilaksanakan oleh kabupaten harus pindah di propinsi seperti halnya masalah pertambangan, sehingga ada kewajiban untuk melimpahkan dukungan sarana, penganggaran dan personil yang dibatasi limitasi waktu tertentu.

Dalam beleid itu disebutkan bahwa bupati dan walikota tidak lagi berwenang menetapkan wilayah usaha pertambangan (WIUP) serta izin usaha pertambangan (IUP) ke perusahaan. Kewenangan itu kini hanya dimiliki gubernur, dan pemerintah pusat. Perinciannya: Pemerintah Provinsi (Pemprov) berwenang menetapkan wilayah izin usaha pertambangan (WIUP) di areal tambang yang ada di wilayahnya. Adapun daerah tambang lintas provinsi menjadi kewenangan pusat yang diwakili Kementerian Energi dan Sumber Daya Mineral (ESDM).

Dalam pengelolaan usaha pertambangan selalu terjadi hubungan infromal yang terjadi dalam praktik pertambangan, dimana sebagian besat karena adanya kepentingan ekonomi. Sebagaimana dalam dunia usaha, siapa yang ememiliki modal besar maka dialah yang memiliki peluang maupun aktor yang paling berperan dan saling mempengaruhi. Namun tidak semua pihak bergerak atas nilai ekonomi yang ada. Kepentingan sosial dalam jejaring aktor ini terbagi dalam dimensi ekonomi dan lingkungan, dimana 
masyarakat tidak memiliki akses terhadap sumber daya alam tersebut, sebaliknya masyarakat merasakan dampak negatif dari usaha pertambangan yang ada.

Berdasarkan pada kerangka normatif yang dibangun oleh Undang-undang No. 4 Tahun 2009 tentang Pertambangan dan Mineral Batubara, terdapat 3 dimensi utama yakni ekonomi, sosial, dan lingkungan hidup. Dimana ini telah tertuang dalam Permen Lingkungan Hidup No. 17 Tahun 2012 tentang Pedoman Keterlibatan Masyarakat dalam Proses Analisis Dampak lingkungan. Dimana peran aktif masyarakat berperan dalam pengambilan suatu kebijakan oleh pemerintah. Sedangkan dalam aspek lingkungan Hidup pada Undang-undang N0. 32 Tahun 2009 tentang Perlindungan dan Pengelolaan lingkungan Hidup menyatakan bahwa lingkungan hidup sebagai prisip dalam konsep "Good Mining Practice" yang kemudian diasopsi dalam PP No. 78 Tahun 2010 tentang Reklamasi dan Pasca Tambang, tidak hanya itu saja konsep ini juga sudah diadopsi sebagai kebijakan sektoral di bidang pertambangan di tingkat Kabupaten/Kota yang tertuang dalam Renstra SKPD dan Renstra Kab/Kota. Sedangkan sisi ekonominya, dari UU No. 4 Tahun 2009 tersebut diturunkan dalam PP 23 Tahun 2010 dimana regulasi tersebut mengandung upaya untuk meningkatkan pendapatan masyarakat dari sektor pengelolan industri pertambangan. ( Nurhayati dan Suhirman, Jurnal Perencanaan Wilayah dan Kota B SAPPK V2N3. Hal. 711) Kemudian dari adanya kegiatan pertambangan yang ada tersebut tentunya terdapat pihak-pihak yang berkentingan diantaranya: ( Nurhayati dan Suhirman, Jurnal Perencanaan Wilayah dan Kota B SAPPK V2N3. Hal. 718): 1. Bupati; 2. DPRD; 3. Pengusaha; 4. Kantor Lingkungan Hidup; 5. Asosiasi pengusaha Tambang; 6. Media dan Ormas; 7. Dinas pertambangan dan energi

Sedangkan dalam proses legislasi di daerah yang mana sampai pada saat ini masih perlu dilakukan sinergitas antar pendukung dan dasar pengaturan dari suatu rancangan peraturan daerah, maka perlu dilakukan suatu legal audit ats peraturan daerah yang berkaitan dengan masalah perizinan pertambangan yang dulunya merupakan kewenangan yang dimiliki oleh Pemerintah Daerah Provinsi, dan Pemerintah Kabupaten/Kota.
Adapun caranya dengan mengidentifikasi beberapa permasalahan yang menyangkut hal-hal sebagai berikut: (Tim Peneliti Pusat Pengembangan Otonomi Daerah Universitas Brawijaya): 1) kebaruan (up to date) dasar yuridis pembentukan peraturan daerah; 2) kesesuaian dengan teknik legislatif drafting; 3) diskoneksi tujuan dan isi ( konsistensi pasal); 4) kejelasan obyek dan subyek pengaturan: 5) efektifitas dan efisiensi kinerja birokrasi (good governance); 6) bentuk pengelolaan pertambangan mineral; 7) pedoman pengelolaan pertambangan mineral daerah; 8) persaingan sehat dan dampak ekonomi negatif; 9) aksesibilitas dan partisipasi masyarakat; 10) kesesuaian proses pengelolaan, pembinaan dan pengawasan pertambangan yang transparan; 11) sanksi (administrasi dan pidana).

\section{SIMPULAN}

Pasca pemberlakuan undang-undang Pemda baru pemerintah daerah tingkat Kabupaten/Kota tidak lagi memiliki kewenangan untuk mengeluarkan izin pertambangan, sebagaimana amanah dari Undang-undang No. 23 Tahun 2014 tentang Pemerintah Daerah yang tercantum dalam lampiran undang-undang tersebut yang sudah menjadi satu kesatuan yang tidak terpisahkan dalam pengaturan suatu produk peraturan perundang-undangan. Perlu adanya upaya sinkronikasi produk peraturan perundangundangan di daerah yang mengatur hal-hal yang terkait dengan perizinan pertambangan di daerah.

Untuk lebih mengoptimalkan pengelolaan pertambangan di daerah, hendaknya daerah perlu menyesuaikan dengan peraturan terbaru yang berkaitan dengan pengelolaan pertambangan terutama hal yang berkaitan dengan perizinan pertambangan karena adanya perubahan kewenangan dalam pelaksanaan urusan pemerintahan di bidang pertambangan dengan melakukan upaya perubahan mellaui pencabutan dengan menerbitkan peraturan daerah baru. Untuk meminimalisir adanya pengelolaan pertambangan illegal maka pemerintah daerah disarankan untuk terus melakukan sosialisasi terkait dengan aturan baru mengenai pengelolaan pertambangan yang ada dan memberikan informasi yang sejelasjelasnya kepada masyarakat luas. 


\section{DAFTAR RUJUKAN}

\section{Literatur:}

Bagir Manan, Menyongsong Fajar Otonomi Daerah, (Yogyakarta : Pusat Studi Hukum UII, 2004).

Soepomo dalam Sri Nur Hari Susanto, Penguasaan Daerah Atas Bahan Galian/ Pertambangan dalam Perspektif Otonomi Daerah, Hal. 5 Makalah disampaikan pada Seminar Nasional Aspek Hukum Penguasaan Daerah Atas Bahan Galian, di Fakultas Hukum Undip pada 2 Desember 2009.

Yunie Nurhayati dan Suhirman, Dinamika Kelmbagaan Pengelolaan Sumber daya Alam Dalam Konteks Pembangunan Berkelanjutan (Studi Kasus: Pertambangan Pasir Besi Di Kabupaten Tasikmalaya. Jurnal Perencanaan Wilayah dan Kota B SAPPK V2N3

\section{Internet:}

http://www.article33.or.id/a/id/3/tata-kelolaekstraktif/128-regulasi-pertambangan-dan- pembangunan-ekonomi diakses pada tanggal 28 September 2015 pukul 10.02

http://www.negarahukum.com/hukum/legalaudit.html dalam Legal Audit oleh Maskun diakses tanggal 27 September 2015 pukul 12.30

Isran Noor. Pelaksanaan Desentralisasi Setengah Gagal. Diakses dalam www.borneomagazine.com diakses tanggal 28 September 2015 pukul 15.04 WIB

Peraturan Perundang-undangan:

Undang-undang No. 9 Tahun 2015 tentang Perubahan Kedua Undang-undang No. 23 Tahun 2014 tentang Pemerintah Daerah Undang-undang N0. 4 Tahun 2009 tentang Pertambangan dan Mineral Batubara

Undang-undang No.5 Tahun 1960 tentang Pokokpokom Agraria

Peraturan Menteri Dalam Negeri No. 1 Tahun 2014 tentang Pembentukan Produk Hukum Daerah. 